\title{
Morality, Activism and Radicalism in the Brazilian Left and the Brazilian Right
}

\author{
Mario Gloria Filho*, 1 \\ Orcid.org/0000-0002-9029-7076 \\ João Gabriel Modesto ${ }^{1,2}$ \\ Orcid.org/0000-0001-8957-7233 \\ ${ }^{I}$ Centro Universitário de Brasília (UNICEUB), Brasilia, DF, Brasil \\ ${ }^{2}$ Universidade Estadual de Goiás (UEG), Formosa, GO, Brasil
}

\begin{abstract}
In the last few years, there has been a rising tension in Brazilian politics between individuals who identify as left-wing and those who identity as right-wing. Sometimes those tensions have resulted in radical behavior from people who identify with either side of the political spectrum. This paper has two main goals: (a) to investigate (using the Moral Foundations Theory as a basis) the moral matrices of participants who identify as being left, center-left, center-right, and right; and (b) to compare the indices of activism and radicalism between participants with different political orientations. There were 226 participants in the study, most of which were from the Federal District (64.16\%). The participants answered an online survey composed of the Moral Foundations Questionnaire, the Activism and Radicalism Intention Scale, and informed demographic data (including their political preference). Differences were found in the moral matrices of participants with different political positions. Higher indices of activism and radicalism were found among participants who self-declared as being left and center-left. Based on the field's literature, the perception of unfairness held by individuals who identify as left in the current political context may help to understand these findings.
\end{abstract}

Keywords: Moral Foundations Theory, political activism, political radicalism, Political Psychology.

\section{Moralidade, Ativismo e Radicalismo na Esquerda e na Direita Brasileira}

\section{Resumo}

Nos últimos anos foi possível observar na política brasileira o acirramento de tensões entre indivíduos que se declaram de direita e de esquerda. Essas tensões, não raramente, resultaram em comportamentos radicais em pessoas que se identificam com ambos os lados do espectro político. Frente a esse contexto, o presente trabalho possuiu dois objetivos principais: (a) investigar as matrizes morais (tendo como base a Teoria dos Fundamentos Morais) de participantes que se identificam como de esquerda, centroesquerda, centro-direita e direita e (b) comparar os índices de ativismo e radicalismo entre participantes com essas diferentes posições políticas. Participaram do estudo 226 pessoas, sendo a maioria do Distrito

* Mailing address: Centro Universitário de Brasília, Faculdade de Ciências da Saúde, Departamento de Psicologia, SEPN 707/907, Campus Universitário - Asa Norte, Brasília - DF, Brasil 70790-075. E-mail: gloriafilho.mario@gmail.com. 
Federal (64.16\%). Os participantes responderam a um instrumento online composto pelo Questionário de Fundamentos Morais, escala de Ativismo\Radicalismo e informaram dados demográficos (incluindo o próprio posicionamento político). Foram encontradas diferenças nas matrizes morais dos participantes com diferentes posições políticas. Foram ainda encontrados maiores índices de ativismo e radicalismo entre participantes que se autodeclararam de esquerda. Tendo como base a literatura na área, a percepção de injustiça vivenciada por parte de membros da esquerda brasileira no atual contexto político do país pode favorecer a compreensão dos achados da presente pesquisa.

Palavras-chave: Fundamentos morais, ativismo político, radicalismo político, Psicologia Política.

\section{Moralidad, Activismo y Radicalismo en la Izquierda y Derecha Brasileña}

\section{Resumen}

En los últimos años fue posible observar en la política brasileña el aumento de tensiones entre individuos que se declaran de derecha y de izquierda. Estas tensiones, no raramente, resultaron en comportamientos radicales de personas que se identifican con ambos lados del espectro político. En este contexto, el presente trabajo tuvo dos objetivos principales: (a) investigar las matrices morales (teniendo como base la Teoría de los Fundamentos Morales) de participantes que se identifican como de izquierda, centro izquierda, centro derecha y derecha y (b) comparar los índices de activismo y radicalismo entre participantes con esas diferentes posiciones políticas. Participaron del estudio 226 personas, siendo la mayoría del Distrito Federal (64.16\%). Los participantes respondieron a un instrumento online compuesto por el Cuestionario de Fundamentos Morales, escala de Activismo/ Radicalismo e informaron datos demográficos (incluyendo el propio posicionamiento político).Se encontraron diferencias en las matrices morales de los participantes con diferentes posiciones políticas Se encontraron aún mayores índices de activismo y radicalismo entre participantes que se auto-declararon de izquierda. Con base en la literatura del área, la percepción de injusticia vivenciada por parte de los miembros de la izquierda brasileña en el actual contexto político del país puede favorecer la comprensión de los hallazgos de la presente investigación.

Palabras clave: Fundamentos morales, activismo político, radicalismo político, Psicología Política.

Brazilian society has been witnessing several demonstrations of popular outrage over national politics. Dissatisfaction with the political situation in Brazil seems to come from both sides of the political spectrum (the left and the right), which can be observed in debates on social media, daily conversations and news coverage on numerous media outlets ("Brazil media reaction," 2016; da Rocha, 2017). This political dissatisfaction is clear in the voting intention polls for possible presidential candidates in the 2018 elections, in which blank and null votes appear in higher percentage than the highest-ranking candidate (Datafolha Instituto de Pesquisa, 2018). The 2018 election's outcome also showed that the percentage of null votes has been the highest since Brazils re-democratization in 1989 (Grandin, Oliveira, \& Esteves, 2018). Despite the apparently generalized dissatisfaction, many people in the country treat national politics as if it were a soccer game presuming that political parties were rival teams. It is no wonder that the expression "the Fla vs. Flu of politics" (in reference to two rival teams in national Brazilian soccer) has become commonplace among Brazilians (Carpanez, 2017; Mello, 2017). In this "Fla vs. Flu," it is common to see misunderstandings of the "rival's" ideas and mutual allegations that the other party is radical and not open to dialogue.

Identifying with different political ideologies is a right ensured by the Brazilian 
Federal Constitution of 1988, and it reflects the individual liberty professed by both democracy and modernity (Marcondes, 1997). The identification with different political parties and the freedom to express different opinions are, therefore, legitimate and a part of the democracy game.

One way to understand the identification with political stances is through Moral Foundations Theory (MFT; Haidt, 2012). According to the theory, different political opinions exist due to differences in the moral matrices of groups that identify as being left or right (Federico, Weber, Ergun, \& Hunt, 2013; Graham, Haidt, \& Nosek, 2009; Haidt, 2012; Haidt \& Graham, 2007; Haidt \& Joseph, 2011; Haidt, Rosenberg, \& Hom, 2003).

In addition to the causes (i.e., moral foundations), it is also important to analyze possible consequences of the identification with political stances. To what extent can people with a certain political stance present higher indices of radicalism than those who adopt a different political position? This paper has two main goals: (a) to investigate the moral matrices of participants who identify as being left, centerleft, center-right, and right; and (b) to compare the indices of activism and radicalism between participants who identify with different political stances.

\section{Human Morality and Politics}

The study of human morality has been changing with advances in moral psychology (Koleva, Graham, Iyer, Ditto, \& Haidt, 2012). In the early 1990s, it was noted that discussions about certain topics in U.S. politics (especially issues related to sex, gender, and family life) resulted in profound divisions in society (James, 1991). One hypothesis is that those misunderstandings were caused mainly by disagreement on the nature of moral authority. On one side of these culture wars were the "orthodox," who believed that moral truths existed regardless of human will and were based on a transcendent and clear authority. On the other side were the "progressives," who did not see moral truths as finalized works but as changeable and interpretable according to generations and the passage of time (James, 1991).

Other disagreements were found when the perspectives of U.S. liberals and conservatives were analyzed. For instance, Americans tend to see their country as a family and their government as a father figure (Lakoff, 1997). Nevertheless, there is disagreement regarding the cognitive model of family they prefer. Conservatives prefer a "family" led by a strict father who imposes discipline for the sake of the children in a world full of danger and competition. Liberals, on the other hand, prefer a compassionate father who provides his children with resources and freedom to develop their talents in a relatively safe and cooperative world.

In addition, a meta-analysis found that basic personality traits are can predispose some individuals to become conservative or liberal (Jost, Glaser, Kruglanski, \& Sulloway, 2003). It was verified that conservatives have a greater need for order, structure, and need for closure when compared to liberals. They also have a lower tolerance for ambiguity and are less open to experimenting. Furthermore, they display higher levels of anxiety over death and fear of threats to the stability of the social system.

James (1991), Jost et al. (2003), and Lakoff (1997) present different perspectives on the group disagreements over moral issues, but they converge on one point: these disagreements can be widely attributed to disparate preferences regarding a taste for change versus a taste for stability, as well as to the tension between hierarchy and equality. Hierarchy tends to require stability while equality change. However, more recent developments in moral psychology suggest that the division between liberals and conservatives is even more multidimensional and complex (Baldner, Pierro, Chernikova \& Kruglanski, 2018; Graham et al., 2009; Graham, Haidt, Iyer, \& Ditto, 2011; Haidt, 2012).

\section{Moral Foundations}

Moral Foundations Theory was based on several evolutionary and anthropological connections to human morality (Graham et al., 2009). Moral institutions derive from innate 
psychological mechanisms that have evolved along with cultural practices and institutions (Richerson \& Boyd, 2005). The definition of "innate" employed by Moral Foundations Theory is equivalent to the notion of "organized before experiencing" not "determined by genetics" (Marcus, 2004). That is, these innate mechanisms guide the agents of socialization but do not determine cultural values and practices. The theory proposes that five moral foundations are universally available and compose an intuitive ethics. Each foundation produces quick, automatic, and intuitive reactions of enjoyment or dislike when certain patterns are observed in the social world. These quick, automatic, and intuitive reactions consequently become guides to what is right or wrong.

The first foundation proposed is care. This foundation is related to the evolution of humans as mammals with systems of attachment and the ability to feel and dislike the pain and suffering of others. It is the basis for virtues such as kindness, amiability, and the capacity to give protection, and it contributes to people's disapproval of individuals who cause pain and suffering. Evidence that supports this foundation can be found in studies of empathy (de Waal, 2008) and in the Theory of Attachment (Bowlby, 1969).

The second moral foundation is fairness. This foundation is related to the evolutionary process of reciprocal altruism. It generates the ideas of justice, rights, and autonomy. It includes the notions of equality, which is more important to liberals, and proportionality, which is more important to conservatives. This foundation makes individuals more sensitive to issues of equality and justice, leading them to turn against people who violate such principles. Research on reciprocal altruism was the main theoretical basis for this foundation (Trivers, 1971).

These two moral foundations constitute the individualizing tendency and are the main sources of the liberal moral intuition, which emphasizes the rights and social welfare of individuals (Graham et al., 2009). The individualizing tendency is typically emphasized in Western societies, given its relevance to the regulation of social life in market democracies (Haidt \& Graham, 2007). It was also a predictor of voting intentions for candidates of liberal parties in the U.S. 2012 elections (Franks \& Scherr, 2015).

The third foundation is loyalty, which is related to the long tribal history of human beings and their capacity to form varied coalitions. It is the basis for characteristics such as patriotism, self-sacrifice for the group, attachment to family and church, and vigilance against traitors. This foundation is activated every time people have a "one for all and all for one" feeling, and it leads people to approve of individuals who contribute to the cohesion and welfare of the group they belong to. This foundation is derived from works on coalitional psychology (Kurzban, Tooby \& Cosmides, 2001).

The fourth moral foundation is authority. This foundation is based on the human tendency for creating hierarchically structured societies. It approves of individuals who display good leadership or obedience, performing functions in the social structure. It was formed based on the long primate history of social interactions. It is the basis for characteristics such as the deference to authority and respect for tradition. This foundation was motivated by research on the evolution of hierarchy in primates (de Waal, 1982) and on the need for subordinates to accept hierarchy in order for it to exist (Boehm, 1999).

The fifth foundation is sanctity. This foundation is based on the emotion of disgust in response to biological and social contaminants such as spiritual corruption or the inability to control urges and impulses. It is the basis for religious notions such as the desire to live in a more "elevated," less carnal, and nobler way. The idea that the body is a temple that can be desacralized by immoral activities or contaminants tends to align with this foundation. This foundation was inspired by studies on the psychology of disgust (Rozin, Haidt, \& McCauley, 2008).

The latter three moral foundations constitute the "binding tendency" and are the main sources of the conservative moral intuition, which places special emphasis on authority, loyalty, and sanctity. The binding tendency is higher among individuals that see the world as a dangerous, 
threatening place, as well as among people who display higher levels of religiousness (Franks \& Scherr, 2015). It also acted as a predictor of voting intention for candidates of conservative parties in the U.S. 2012 elections (Franks \& Scherr, 2015).

The intensity with which each individual adheres to these moral foundations is widely associated with their political tendencies (Franks \& Scherr, 2015). People who tend to emphasize fairness and care (the individualizing tendency) instead of loyalty, authority, and sanctity (the binding tendency) are more inclined to liberal political ideas, more open to social changes, and less attached to tradition. The tendency of people who associate with liberal political parties to endorse the individualizing tendency has been demonstrated in several studies (Federico et al., 2013; Franks \& Scherr, 2015; Graham et al., 2009; Graham et al., 2011; Koleva et al., 2012). On the other hand, those who emphasize all five foundations, but especially the ones concerning the binding tendency, display a preference for political parties of conservative orientation, are more attached to traditional institutions, and are more resistant to social changes, which is also demonstrated in different studies (Federico et al., 2013; Franks \& Scherr, 2015; Graham et al., 2009; Koleva et al., 2012).

Besides favoring the understanding of specific political stances (liberal vs. conservative), the moral foundations also contribute to the understanding of various phenomena often discussed within the political scope such as punitive sentences (Silver \& Silver, 2017), homophobia (Barnett, Öz, \& Marsden, 2018), attitudes about rape (Barnett \& Hilz, 2018), and pro-environment attitudes (Wolsko, 2017). This research has also started a discussion on the extent to which the Moral Foundations Theory (MFT) can be understood as a Political Ideology Theory (see Smith, Alford, Hibbing, Martin, \& Hatemi, 2017 for a more detailed discussion).

\section{Activism and Radicalism}

In addition to understanding the causes (moral foundations) that favor certain political stances, it is also important to analyze the possible consequences they bring. Owing to the level of intolerance that permeates daily discussions about Brazilian politics, it is important to understand aspects of political activism and radicalism and their relations to the different political stances.

Political activism can be defined as the participation in legal and non-violent activities for a cause. Political radicalism, in turn, is characterized as the engagement in illegal and violent activities for a cause (Moskalenko \& McCauley, 2009). Although this definition is more centered on the action itself, it is necessary to highlight that the process of radicalization can be separated into radicalization of opinions and radicalization of actions (McCauley \& Moskalenko, 2016, 2017). Not always will radical opinions effectively convert into radical actions. There is a series of variables at different levels of analysis involved with understanding of the radicalism process (della Porta, 2018; McCauley \& Moskalenko, 2016; Soliman, Bellaj, \& Khelifa, 2016; van Stekelenburg, 2017).

As a first understanding of the phenomenon, radicalism of actions would be the result of a process similar to the idea of a "moving walkway," meaning that the individual would gradually move from activism toward radicalism (Moskalenko \& McCauley, 2009). This does not imply that all activists become radicals; it means that in order to get to radicalism, the individual will have already gone through the walkway of activism. Seeking to refine the distinction between action radicalism and opinion radicalism, the Two-Pyramids Model was proposed (McCauley \& Moskalenko, 2016, 2017). This model is based on evidence from social psychology indicating that attitudes do not necessarily predict behavior.

According to the authors, there are two pyramids: the opinion and the action. The first would be composed of a neutral basis, which includes people who do not care about political issues. Above the basis would be the sympathizers, who believe in certain political causes but do not find the use of violence to achieve them justifiable. One level above 
that would be the justifiers, who believe that violence in certain cases is justifiable. At the top of the pyramid would be those who feel morally obliged to use force to defend a cause.

With respect to the action pyramid, the basis would be composed of individuals who take no political actions at all (the inerts). Above the inerts would be the activists, people who engage in legal political actions. One level above that would be the radicals, individuals who engage in illegal political actions. At the top of the pyramid would be the terrorists, who engage in illegal political actions that affect civil society. It is important to highlight that, in both pyramids, individuals can move from the bottom to the top and from the top to the bottom, skipping levels. That means it is not a model of gradual stages (McCauley \& Moskalenko, 2017). Despite the distinction between the pyramids, in some cases there is evidence of an established relationship between radical opinions and actions (McCauley \& Moskalenko, 2014).

The perception of unfairness is one factor that contributes to the understanding of the gradual moving toward political radicalism (Bal \& van den Bos, 2017; Doosje, Loseman, \& van den Bos, 2013; Doosje, van den Bos, Loseman, Feddes, \& Mann, 2012). The perception of unfairness may favor the rejection of the system in place. In the case of radical groups who present themselves as a channel for change in the system, it is more likely that these individuals will present higher indices of radicalism (Bal \& van den Bos, 2017). When an individual loses their identification with a country or its rulers, radicalism is more likely to occur (Moskalenko \& McCauley, 2009).

Despite the different variables that may interfere with the indices of activism and especially radicalism, we believe that the elements related to unfairness have an important role in the analysis of activism and radicalism of individuals with both right and left political stances in the current Brazilian context. The impeachment of former president Dilma Rousseff in August 2016 was seen by the Brazilian left as a "parliamentary coup," and the arrest of former president Luís Inácio "Lula" da Silva was seen by many as a way to prevent him from running in the presidential elections of 2018. When both episodes happen to a left-wing party, it is possible that these events come to favor the perception of unfairness by individuals aligned with a left political stance, which may then contribute to higher indices of radicalism.

\section{Study's Overview}

This research has two main goals: (a) to investigate the moral matrices of individuals who identify with different political stances; and (b) to compare the indices of activism and radicalism between participants of different political stances.

In relation to the first goal, we formulated the hypothesis (H1) that, according to research findings developed in other countries, the Brazilian left would display a moral matrix mostly based on the foundations of care and justice (the individualizing tendency), and the right (H2) would display a moral matrix based on the foundations of authority, loyalty, and sanctity (the binding tendency).

As to the second goal, we hypothesized that four different groups (left, center-left, centerright, and right) would display differences in the indices of political activism and radicalism. We also predicted that the indices of political activism would be higher among people who identify with progressive stances (i.e., leftwing stances in Brazil), as the Brazilian left usually aligns with the ideological defense of social changes, which permeates the need for political activism (H3). Beyond the defense of social change, the historical portrait of the current Brazilian political context may favor a perception of unfairness by the members who identify as left, which would contribute to higher indices of radicalism in left-leaning individuals (H4). We believe these hypotheses, connected to the current Brazilian reality, contribute to a contextual social psychology, in which psychological phenomena are analyzed in relation to the specific social contexts in which they emerge (Pettigrew, 2018). 


\section{Method}

\section{Participants}

The research was carried out using a group of 226 people randomly sampled from numerous social media platforms. Most of the sample consisted of women (61.1\%). Their ages varied between 18 and 71 years old $(M=$ $37.69 ; S D=12.96)$. Of the 226 participants, 55 $(24.30 \%)$ identified as being left, $67(29.60 \%)$ as center-left, $62(27.40 \%)$ as center-right, and $42(18.60 \%)$ as right. Of the 27 Brazilian states, $16 \mathrm{had}$ at least one participant in the research; $63.30 \%$ of the sample was from the Federal District (DF), $10.60 \%$ from the state of Rio de Janeiro (RJ), 7.10\% from Amazonas (AM), and the remaining states were represented in smaller numbers.

In relation to financial income, 39 (17.50\%) participants declared earning between 2,747 and 8,241 USD per year, 39 (17.50\%) declared earning between 8,241 and 16,494 USD per year, 47 (21.10\%) declared earning 16,494 and 24,720 USD per year, 98 (43.90\%) declared earning more than 27,491 USD per year, and 3 $(1.30 \%)$ did not wish to declare their earnings. All earnings were converted to USD using the 4.09 exchange rate on September 25, 2018 and are based on the Brazilian minimum wage of 2018 (937 BRL).

Concerning education, $2.70 \%$ of the sample had access to basic education, $8.80 \%$ declared finishing high school, $64.20 \%$ attended university at the undergraduate level, and $23.40 \%$ finished a graduate degree.

\section{Instruments}

The survey was conducted using a version of the Moral Foundations Questionnaire (MFQ; Graham et al., 2009) adapted to Brazil (Silvino et al., 2016) and the Activism and Radicalism Intention Scale (ARIS; Moskalenko \& McCauley, 2009). The MFQ was composed of 32 items divided into two parts, each containing 16 items that assess the five moral foundations proposed by the theory. On the first part of the questionnaire participants were required to indicate the relevance of certain statements to decide whether something was right or wrong. Each of the 16 statements was assessed with a Likert scale in which $1=$ not relevant at all, $2=$ not very relevant, $3=$ slightly relevant, 4 $=$ moderately relevant, $5=$ very relevant, and 6 extremely relevant. On the second part of the questionnaire participants were required to mark the alternative that best described their behavior in a situation. Each of the 16 statements was assessed with a Likert scale in which $1=$ not likely at all, $2=$ not very likely, $3=$ slightly likely, $4=$ moderately likely, $5=$ very likely, and $6=$ extremely likely.

During the Brazilian validation of the MFQ, it was observed a tendency for the moral foundations of harm and justice to group together, forming the individualizing tendency. The moral foundations of loyalty, authority, and sanctity also presented a tendency to group together, forming the binding tendency. These patterns were also found on the adaptation of the MFQ to other countries (Silvino et al., 2016). In the validation study, the factor referring to the individualizing tendency presented an alpha of 0.91 , and the factor referring to the binding tendency presented an alpha of 0.87 (Silvino et al., 2016). In this study, the internal consistency referring to the individualizing and binding tendencies were $\alpha=0.78$ and $\alpha=0.85$, respectively.

The Activism and Radicalism Intention Scale (ARIS; Moskalenko \& McCauley, 2009) was composed of 10 statements that assessed the individual intention to activist and radical behaviors. In the ARIS, political activism and radicalism are understood as two distinct scopes, which means that radicalism is not seen as activism taken to the extreme but as a distinct phenomenon.

Each of the 10 statements was assessed on a Likert scale in which $1=$ not likely at all, $2=$ not very likely, $3=$ slightly likely, 4 $=$ moderately likely, $5=$ very likely, and $6=$ extremely likely. Items 1 through 5 on the scale measured the participants' intention to activism with sentences such as: "I would participate in an organization that fights for my group's legal 
and political rights" or "I would donate money to an organization that fights for my group's legal and political rights."

Items 6 through 10 measured the participants' propensity to radicalism with sentences such as: "I would participate in a public protest against the oppression of my group, even if such protest could turn violent" or "I would attack the police or security forces if I saw them attack members of my group."

In the original study, the activism scope presented an alpha of 0.86 , and the radicalism scope presented an alpha of 0.83 (Moskalenko $\&$ McCauley, 2009). In this study, the activism scope presented Cronbach's alpha of 0.66 , while the radicalism scope presented an alpha of 0.76 .

\section{Procedure}

Before answering the questionnaires, participants were invited to accept the terms and conditions of the research. The terms highlighted the conditions of secrecy, confidentiality, risks, and the voluntary nature of the participation. After those conditions were explained and accepted the survey could start being answered.

Data were collected anonymously, and the average time each participant took to complete the questionnaires was 15 minutes. Data collection was widely publicized on social media platforms and occurred online using Google Forms. The participants first answered the Moral Foundations Questionnaire and secondly the Activism and Radicalism Intention Scale.

\section{Data Analysis}

All statistical parameters used in this paper have been tested prior to use. Analyses of variance were carried out to compare the indices of moral foundations and of activism and radicalism among participants with distinct political stances.

\section{Ethical Procedures}

This research did not present any physical, moral, or psychological risks to the participants, and it was conducted according to the ethical principles of research with humans postulated by the American Psychological Association. All participants agreed to engage voluntarily under ensured anonymity of the given information.

\section{Results}

Aiming to test the hypothesis that the Brazilian political left, center-left, centerright and right are guided by distinct moral foundations, an ANOVA with a Bonferroni posthoc test was conducted. As hypothesized (H1), higher indices for the individualizing tendency were found in participants who self-declared as left $(M=5.06 ; S D=0.61)$, followed by centerleft participants $(M=4.77 ; S D=0.73)$, centerright $(M=4.58 ; S D=0.66)$, and right $(M=4.54$; $S D=0.89), F(3,222)=5.60, p=.001, \eta^{2} \mathrm{p}=0.07$. Bonferroni tests verified that the differences were concentrated in the comparisons between left and center-right and between left and right. No significant difference was found in the levels of individualizing tendency between left and center-left, as can be observed in Table 1 .

In the comparisons of morality indices between different political groups, marginally significant results were found in the direction of the hypothesis (H2), which predicted higher indices of the binding tendency in participants who self-declare as right $(M=3.84 ; S D=0.93)$, followed by center-right participants $(M=3.71$; $S D=0.89)$, left $(M=3.52 ; S D=0.84)$, and center-left $(M=3.43 ; S D=0.73), F(3,222)=2.52$, $p=.059, \eta^{2} \mathrm{p}=0.03$. Bonferroni tests verified that the differences were marginally significant, concentrating primarily between the stances of right and center-left, as can be observed in Table 2. No other significant differences were found.

After that, differences between the indices of activism were tested comparing the different political stances. As hypothesized (H3), higher indices of activism were found for participants who self-declared as left-wing $(M=3.82 ; S D$ $=0.92)$, followed by center-left participants $(M=3.45 ; S D=0.96)$, center-right $(M=3.18$; $S D=1.01)$, and right-wing $(M=3.18 ; S D=$ $0.99), F(3,222)=5.19, p=.002, \eta^{2} p=0.06$. Bonferroni tests verified that the differences were concentrated in the comparisons between 
Table 1

Post-Hoc Bonferroni Test: Multiple Comparisons of Individualizing Tendency Levels between Different Political Stances

\begin{tabular}{llccccc}
\hline \hline Stance & \multicolumn{1}{c}{} & & & \multicolumn{2}{c}{ 95\% Confidence Interval } \\
\hline Left & Comparison & $\begin{array}{c}\text { Difference } \\
\text { between means }\end{array}$ & $\begin{array}{c}\text { Standard } \\
\text { Deviation }\end{array}$ & Sig. & Inferior & Superior \\
& Center-left & 0.28 & 0.13 & 0.202 & -0.06 & 0.62 \\
& Center-right & 0.47 & 0.13 & 0.003 & 0.11 & 0.82 \\
& Right & 0.51 & 0.14 & 0.004 & 0.11 & 0.90 \\
Center-left & Left & -0.28 & 0.13 & 0.202 & -0.62 & 0.06 \\
& Center-right & 0.19 & 0.12 & 0.772 & -0.14 & 0.53 \\
& Right & 0.23 & 0.14 & 0.625 & -0.14 & 0.60 \\
Center-right & Left & -0.47 & 0.13 & 0.003 & -0.82 & -0.11 \\
& Center-left & -0.19 & 0.12 & 0.772 & -0.53 & 0.14 \\
& Right & 0.03 & 0.14 & 1.000 & -0.34 & 0.42 \\
& Left & -0.51 & 0.14 & 0.004 & -0.90 & -0.11 \\
& Center-left & -0.23 & 0.14 & 0.625 & -0.60 & 0.14 \\
& Center-right & -0.03 & 0.14 & 1.000 & -0.42 & 0.34 \\
\hline
\end{tabular}

Table 2

Post-Hoc Bonferroni Test: Multiple Comparisons of Binding Tendency Levels between Different Political Stances

95\% Confidence Interval

\begin{tabular}{llccccc}
\hline Stance & Comparison & $\begin{array}{c}\text { Difference } \\
\text { between means }\end{array}$ & $\begin{array}{c}\text { Standard } \\
\text { Deviation }\end{array}$ & Sig. & Inferior & Superior \\
\hline Left & Center-left & 0.08 & 0.15 & 1.000 & -0.32 & 0.49 \\
& Center-right & -0.19 & 0.15 & 1.000 & -0.60 & 0.22 \\
& Right & -0.31 & 0.17 & 0.405 & -0.78 & 0.14 \\
Center-left & Left & -0.08 & 0.15 & 1.000 & -0.49 & 0.32 \\
& Center-right & -0.28 & 0.14 & 0.369 & -0.67 & 0.11 \\
& Right & -0.40 & 0.16 & 0.092 & -0.85 & 0.03 \\
Center-right & Left & 0.19 & 0.15 & 1.000 & -0.22 & 0.60 \\
& Center-left & 0.28 & 0.14 & 0.369 & -0.11 & 0.67 \\
& Right & -0.12 & 0.16 & 1.000 & -0.57 & 0.32 \\
\multirow{3}{*}{ Right } & Left & 0.31 & 0.17 & 0.405 & -0.14 & 0.78 \\
& Center-left & 0.40 & 0.16 & 0.092 & -0.03 & 0.85 \\
& Center-right & 0.12 & 0.16 & 1.000 & -0.32 & 0.57 \\
\hline
\end{tabular}


Table 3

Post-Hoc Bonferroni Test: Multiple Comparisons of Activism Levels between Different Political Stances

95\% Confidence Interval

\begin{tabular}{llccccc}
\hline Stance & Comparison & $\begin{array}{c}\text { Difference } \\
\text { between means }\end{array}$ & $\begin{array}{c}\text { Standard } \\
\text { Deviation }\end{array}$ & Sig. & Inferior & Superior \\
\hline \multirow{2}{*}{ Left } & Center-left & 0.37 & 0.17 & 0.225 & -0.10 & 0.84 \\
& Center-right & 0.63 & 0.18 & 0.003 & 0.15 & 1.11 \\
& Right & 0.64 & 0.19 & 0.009 & 0.10 & 1.17 \\
\multirow{3}{*}{ Center-left } & Left & -0.37 & 0.17 & 0.225 & -0.84 & 0.10 \\
& Center-right & 0.26 & 0.17 & 0.729 & -0.19 & 0.72 \\
& Right & 0.26 & 0.19 & 0.965 & -0.24 & 0.78 \\
\multirow{3}{*}{ Center-right } & Left & -0.63 & 0.18 & 0.003 & -1.11 & -0.15 \\
& Center-left & -0.26 & 0.17 & 0.729 & -0.72 & 0.19 \\
& Right & 0.01 & 0.19 & 1.000 & -0.51 & 0.52 \\
\multirow{3}{*}{ Right } & Left & -0.64 & 0.19 & 0.009 & -1.17 & -0.10 \\
& Center-left & -0.26 & 0.19 & 0.965 & -0.78 & 0.24 \\
& Center-right & -0.01 & 0.19 & 1.000 & -0.52 & 0.51 \\
\hline
\end{tabular}

left and center-right and between left and right, as can be observed in Table 3. No significant differences were found between left and centerleft participants.

With respect to the relation between political stances and radicalism, in accordance with our hypothesis (H4), higher indices of radicalism were found in participants who selfdeclared as left $(M=2.41 ; S D=1.10)$, followed by center-left participants $(M=2.00 ; S D=$ $0.93)$, center-right $(M=1.89 ; S D=0.91)$, and right $(M=1.77 ; S D=0.88), F(3,222)=4.39$, $p=.005, \eta^{2} \mathrm{p}=0.05$. Bonferroni tests verified that the differences were concentrated primarily in the comparisons between left and center-right and between left and right, as can be observed in Table 4. Other stances did not present any significant differences.

\section{Discussion}

The goals of this paper were: (a) to investigate the moral matrices of participants who identify as left, center-left, center-right, and right; and (b) to compare the levels of activism and radicalism between participants who identify as left, centerleft, center-right, and right. It was hypothesized (H1) that, as previous studies showed, the Brazilian left would present a moral matrix with stronger emphasis on the foundations of care and fairness (the individualizing tendency), and the right (H2) would present a moral matrix based on the foundations of authority, loyalty, and sanctity (the binding tendency). Furthermore, It was predicted that people who identify as leftwing would present higher indices of activism (H3) and radicalism (H4) when compared to those who identify as right-wing.

The results corroborated $\mathrm{H} 1$ and indicated a statistical tendency toward $\mathrm{H} 2$. As previous articles suggested (Federico et al., 2013; Franks \& Scherr, 2015; Graham et al., 2009; Graham et al., 2011; Koleva et al., 2012), it was verified that individuals with distinct political positions were guided by different moral principles. The left and center-left were guided by the foundations of care and fairness (the individualizing tendency), thus being guided by a morality that is contextual, 
Table 4

Post-Hoc Bonferroni Test: Multiple Comparisons of Radicalism Levels between Different Political Stances

95\% Confidence Interval

\begin{tabular}{llccccc}
\hline Stance & Comparison & $\begin{array}{c}\text { Difference } \\
\text { between means }\end{array}$ & $\begin{array}{c}\text { Standard } \\
\text { Deviation }\end{array}$ & Sig. & Inferior & Superior \\
\hline \multirow{2}{*}{ Left } & Center-left & 0.41 & 0.17 & 0.107 & -0.04 & 0.88 \\
& Center-right & 0.52 & 0.17 & 0.020 & 0.05 & 1.00 \\
& Right & 0.63 & 0.19 & 0.008 & 0.11 & 1.16 \\
\multirow{3}{*}{ Center-left } & Left & -0.41 & 0.17 & 0.107 & -0.88 & 0.04 \\
& Center-right & 0.10 & 0.16 & 1.000 & -0.34 & 0.56 \\
& Right & 0.22 & 0.18 & 1.000 & -0.28 & 0.72 \\
Center-right & Left & -0.52 & 0.17 & 0.020 & -1.00 & -0.05 \\
& Center-left & -0.10 & 0.16 & 1.000 & -0.56 & 0.34 \\
& Right & 0.11 & 0.19 & 1.000 & -0.40 & 0.62 \\
\multirow{3}{*}{ Right } & Left & -0.63 & 0.19 & 0.008 & -1.16 & -0.11 \\
& Center-left & -0.22 & 0.18 & 1.000 & -0.72 & 0.28 \\
& Center-right & -0.11 & 0.19 & 1.000 & -0.62 & 0.40 \\
\hline
\end{tabular}

more open to social change, and less attached to traditions and to the status quo. The right and center-right, on the other hand, presented higher indices on the foundations of loyalty, authority, and sanctity (the binding tendency), thus being more attached to traditional institutions and less open to social changes. These distinct moral tendencies help to understand why, in many cases, people with different political opinions have difficulty establishing a consensus. The moral principles that guide their opinions and actions are different, especially referring to the search for social change (left) in opposition to stability and the maintenance of the status quo (right).

The left's defense of social change was the basis for hypothesis (H3) that individuals who identify as left would present higher indices of political activism when compared to those who identify as right-wing. This hypothesis was also confirmed. Political activism can be understood as the participation in legal and non-violent activities in defense of a cause (Moskalenko
\& McCauley, 2009). Activism is, then, a path toward social change, and that explains the higher levels in left-wing participants, followed by those on the center-left.

Activism, however, is not the only strategy to pursue social change. Political radicalism, illegal or violent activities in favor of a political cause (Moskalenko \& McCauley, 2009), can also be a strategy for transformation. Considering the current Brazilian political context, in addition to evidence for the impact of the perception of unfairness in radicalism (Bal \& van den Bos, 2017; Doosje et al., 2013; Doosje et al., 2012), our hypothesis (H4) that left-wing individuals would present higher indices of radicalism when compared to right-wing individuals was also supported. The impeachment of former president Dilma Rousseff, seen by many as a "parliamentary coup," and the arrest of former president Luís Inácio "Lula" da Silva, seen by members of the Brazilian left as a way to prevent him from running in the presidential elections of 2018, may have contributed to a perception of 
unfairness. This could potentially explain the higher indices of radicalism found among leftwing participants.

When mistrust is established in relation to the political group in power, the tendency to social mobilization (activism) might unfold into political radicalism (van Stekelenburg, 2017) when individuals do not feel represented by the government in power (Moskalenko \& McCauley, 2009). The left might have perceived those events as unfair, which might have contributed to higher indices of radicalism in this group.

Studies suggest that identification with a country and its government is positively correlated with activism (Moskalenko \&McCauley, 2009). Activist intentions might in turn be an expression of care toward a country and a willingness to improve it. Radical intentions, on the other hand, might express a decline in identification with a country or loss of identification with the authorities leading the country (Moskalenko \& McCauley, 2009). When individuals believe their voices are being heard, they tend to conform to the system. On the other side, when they believe they are being ignored, they become more dissatisfied and detached (van Stekelenburg, 2017). It is also important to stress that violence develops as a rejection to harsh forms of repression, which radicalizing agents perceive as brutal and unfair (della Porta, 2018). At a group level, radicalism manifests as an outrageous reaction to unfairness toward a group or a cause (McCauley \& Moskalenko, 2017). Therefore, the search for social change, the perception of unfairness, and the lack of identification with the government in power are relevant for explaining higher indices of both activism and radicalism among those who identify as left and center-left.

There are limitations to the findings of this research. The effects of the perception of unfairness in radicalism have not been tested. There is a theoretical expectation that radicalism would be stronger among those who believe they are being unfairly treated. But for this to be confirmed, it must be tested. Further research will be required to test the impact of the perception of unfairness on the relationship between political positions and radicalism in a Brazilian sample. Additionally, the political radicalism hypothesis derives from a political context permeated by a certain level of turmoil. It is important that the variables analyzed in this study be tested in a different political setting. Only then it would be possible to identify whether the pattern of results is maintained in less polarized political scenarios. The lack of information on whether the sample is affiliated to political parties or not is another limitation. A further limitation relates to the fact that the Activism and Radicalism Intention Scale (ARIS) has not been validated in Brazil what can affect the validity of the instrument when used with a Brazilian sample (Borsa, Damásio, \& Bandeira, 2012). Besides ARIS measures activism and radicalism intentions, not the behavior itself.

Nevertheless, this research makes important contributions. Evidence that the Theory of Moral Foundations favors the understanding of elements of Brazilian politics is presented. Regarding activism and radicalism, hypotheses centered on the Brazilian political context have been formulated and supported. These findings contribute to the development of a Contextual Social Psychology. Presenting evidence of social psychology phenomena, theories, and models in different contexts is essential to making progress in this field (Pettigrew, 2018).

\section{References}

Bal, M., \& van den Bos, K. (2017). From system acceptance to embracing alternative systems and system rejection: Tipping points in processes of radicalization. Translational Issues in Psychological Science, 3(3), 241-253. doi: 10.1037/tps0000123

Baldner, C., Pierro, A., Chernikova, M., \& Kruglanski, A. W. (2018). When and why do liberals and conservatives think alike? An investigation into need for cognitive closure, the binding moral foundations, and political perception. Social Psychology, 1-9. doi: 10.1027/1864-9335/ a000354 
Barnett, M. D., \& Hilz, E. N. (2018). The psychology of the politics of rape: Political ideology, moral foundations, and attitudes toward rape. Violence Against Women, 24(5), 545-564. doi: $10.1177 / 1077801217708887$

Barnett, M. D., Öz, H. C. M., \& Marsden, A. D. (2018). Economic and social political ideology and homophobia: The mediating role of binding and individualizing moral foundations. Archives of Sexual Behavior, 47(4), 1183-1194. doi: 10.1007/s10508-017-0989-2

Boehm, C. (1999). Hierarchy in the Forest: The evolution of Egalitarian Behaviour. Cambridge, MA: Harvard University Press.

Borsa, J. C., Damásio, B. F., \& Bandeira, D. R. (2012). Adaptação e validação de instrumentos psicológicos entre culturas: Algumas considerações. Paidéia (Ribeirão Preto), 22(53), 423-432. doi: 10.1590/ 1982-43272253201314

Bowlby, J. (1969). Attachment and loss. New York: Basic Books.

Brazil media reaction to impeachment vote highlights political divide. (2016, April 18). BBC. Retrieved from https://www.bbc.com/news/world-latinamerica-36075196

Carpanez, J. (2017, December 19). Faltam regras ao Fla X Flu na discussão política, afirma psicanalista sobre ódio na internet. Cotidiano. UOL. Retrieved from https://noticias.uol.com. br/cotidiano/ultimas-noticias/2017/12/19/ faltam-regras-do-fla-flu-na-discussaopolitica-diz-psicanalista-sobre-odio-nainternet.htm

da Rocha, A. P. (2017, August 26). O brasileiro e a desilusão política. Estadão. Retrieved from, https://politica.estadao.com.br/blogs/faustomacedo/o-brasileiro-e-a-desilusao-politica/

Datafolha Instituto de Pesquisa. (2018). Intenção de voto para presidente da república. Retrieved from http://media.folha.uol.com.br/datafolha/ 2018/06/22/08fa14d3cef22ac80a3dcb2427ecda84ivc.pdf

de Waal, F. B. M. (1982). Chimpanzee politics: Power and sex among apes. New York: John Hopkins University Press.

de Waal, F. B. M. (2008). Putting the altruism back into altruism: The evolution of empathy. Annual Review of Psychology, 59(1), 279-300. doi: 10.1146/annurev.psych.59.103006.093625 della Porta, D. (2018). Radicalization: A relational perspective. Annual Review of Political Science, 21(1), 461-474. doi: 10.1146/annurevpolisci-042716-102314

Doosje, B., Loseman, A., \& van den Bos, K. (2013). Determinants of radicalization of Islamic youth in the Netherlands: Personal uncertainty, perceived injustice, and perceived group threat. Journal of Social Issues, 69(3), 586-604. doi: 10.1111/josi.12030

Doosje, B., van den Bos, K., Loseman, A., Feddes, A. R., \& Mann, L. (2012). "My in-group is superior!": Susceptibility for radical rightwing attitudes and behaviors in Dutch youth. Negotiation and Conflict Management Research, 5(3), 253-268. doi: 10.1111/j.17504716.2012.00099.x

Federico, C. M., Weber, C. R., Ergun, D., \& Hunt, C. (2013). Mapping the connections between politics and morality: The multiple sociopolitical orientations involved in moral intuition. Political Psychology, 34(4), 589-610. doi: 10.1111/ pops. 12006

Franks, A. S., \& Scherr, K. C. (2015). Using moral foundations to predict voting behavior: Regression models from the 2012 U.S. presidential election. Analyses of Social Issues and Public Policy, 15(1), 213-232. doi: 10.1111/ asap. 12074

Grandin, F., Oliveira, L., \& Esteves, R. (2018, October 28). Percentual de votos nulos é a maior desde1989; soma de abstenções, nulos e brancos passa de 30\%. Eleições 2018: Eleição em Números. G1. Retrieved from https:// g1.globo.com/politica/eleicoes/2018/eleicaoem-numeros/noticia/2018/10/28/percentualde-voto-nulo-e-o-maior-desde-1989-soma-deabstencoes-nulos-e-brancos-passa-de-30.ghtml

Graham, J., Haidt, J., \& Nosek, B. A. (2009). Liberals and conservatives rely on different sets of moral foundations. Journal of Personality and Social Psychology, 96(5), 1029-1046. doi: 10.1037/ $\mathrm{a} 0015141$

Graham, J., Nosek, B. A., Haidt, J., Iyer, R., Koleva, S., \& Ditto, P. H. (2011). Mapping the moral domain. Journal of Personality and Social Psychology, 101(2), 366-385. doi: 10.1037/ a0021847

Haidt, J. (2012). The Righteous Mind: Why are good people divided by politics and religion? New York: Vintage Books. 
Haidt, J., \& Graham, J. (2007). When morality opposes justice: Conservatives have moral intuitions that liberals may not recognize. Social Justice Research, 20(1), 98-116. doi: 10.1007/ s11211-007-0034-z

Haidt, J., \& Joseph, C. (2011). How moral foundations theory succeeded in building on sand: A response to Suhler and Churchland. Journal of Cognitive Neuroscience, 23(9), 2117-2122. doi: 10.1162/ jocn.2011.21638

Haidt, J., Rosenberg, E., \& Hom, H. (2003). Differentiating diversities: Moral diversity is not like other kinds. Journal of Applied Social Psychology, 33(1), 1-36. doi: 10.1111/j.15591816.2003.tb02071.x

James, D. H. (1991). Culture Wars: The struggle to define America. New York: Basic Books.

Jost, J. T., Glaser, J., Kruglanski, A. W., \& Sulloway, F. J. (2003). Political conservatism as motivated social cognition. Psychological Bulletin, 129(3), 339-375. doi: 10.1037/0033-2909.129.3.339

Koleva, S. P., Graham, J., Iyer, R., Ditto, P. H., \& Haidt, J. (2012). Tracing the threads: How five moral concerns (especially purity) help explain culture war attitudes. Journal of Research in Personality, 46(2), 184-194. doi: 10.1016/j. jrp.2012.01.006

Kurzban, R., Tooby, J., \& Cosmides, L. (2001). Can race be erased? Coalitional computation and social categorization. Proceedings of the National Academy of Sciences, 98(26), 1538715392. doi: 10.1073/pnas. 251541498

Lakoff, G. (1997). Moral Politics: What conservatives know that liberals don't. Chicago, IL: University of Chicago Press.

Marcondes, D. (1997). Iniciação à história da filosofia: dos pré-socráticos a Wittgenstein. Rio de Janeiro, RJ: Zahar.

Marcus, G. F. (2004). The Birth of the mind: How a tiny number of genes creates the complexities of the human thought. New York: Basic Books.

McCauley, C., \& Moskalenko, S. (2014). Toward a profile of lone wolf terrorists: What moves an individual from radical opinion to radical action. Terrorism and Political Violence, 26(1), 69-85. doi: 10.1080/09546553.2014.849916

McCauley, C., \& Moskalenko, S. (2016). Friction: How conflict radicalizes them and us. New York: Oxford University Press.
McCauley, C., \& Moskalenko, S. (2017). Understanding political radicalization: The twopyramids model. American Psychologist, 72(3), 205-216. doi: 10.1037/amp0000062

Mello, B. (2017, April 30). O termo "Fla X Flu" transcende o apelido clássico que decide o carioca. O Globo. Retrieved from https:// oglobo.globo.com/esportes/o-termo-fla-flutranscende-apelido-do-classico-que-decidecarioca- 21277818

Moskalenko, S., \& McCauley, C. (2009). Measuring political mobilization: The distinction between activism and radicalism. Terrorism and Political Violence, 21(2), 239-260. doi: 10.1080/09546550902765508

Pettigrew, T. F. (2018). The emergence of contextual social psychology. Personality and Social Psychology Bulletin, 44(7), 963-971. doi: $10.1177 / 0146167218756033$

Richerson, P. J., \& Boyd, R. (2005). Not by genes alone: How Culture Transformed Human Evolution. Chicago, IL: University of Chicago Press.

Rozin, P., Haidt, J., \& McCauley, C. R. (2008). Disgust. In M. Lewis, J. M. Haviland-Jones, \& L. F. Barret (Eds.), Handbook of Emotions (3rd Ed., pp. 757-776). New York: Guilford Press.

Silver, J. R., \& Silver, E. (2017). Why are conservatives more punitive than liberals? A moral foundations approach. Law and Human Behavior, 41(3), 258-272. doi: 10.1037/ lhb0000232

Silvino, A. M. D., Pilati, R., Keller, V. N., Silva, E. P., Freitas, A. F. de P., Silva, J. N., \& Lima, M. F. (2016). Adaptação do questionário dos fundamentos morais para o português. PsicoUSF, 21(3), 487-495. doi: 10.1590/141382712016210304

Smith, K. B., Alford, J. R., Hibbing, J. R., Martin, N. G., \& Hatemi, P. K. (2017). Intuitive ethics and political orientations: Testing moral foundations as a theory of political ideology. American Journal of Political Science, 61(2), 424-437. doi: 10.1111/ajps.12255

Soliman, A., Bellaj, T., \& Khelifa, M. (2016). An integrative psychological model for radicalism: Evidence from structural equation modeling. Personality and Individual Differences, 95, 127133. doi: 10.1016/j.paid.2016.02.039 
Trivers, R. L. (1971). The evolution of reciprocal altruism. The Quarterly Review of Biology, 46(1), 33-57. doi: 10.1086/406755

van Stekelenburg, J. (2017). Radicalization and violent emotions. PS: Political Science \& Politics, 50(04), 936-939. doi: 10.1017/ S1049096517001020

Wolsko, C. (2017). Expanding the range of environmental values: Political orientation, moral foundations, and the common ingroup. Journal of Environmental Psychology, 51, 284294. doi: 10.1016/j.jenvp.2017.04.005

Recebido: $30 / 07 / 2018$

$1^{a}$ revisão: $13 / 10 / 2018$

$2^{a}$ revisão: $22 / 11 / 2018$

Aceite final: 26/11/2018 